\title{
Development of Guided Inquiry-Based Accounting Learning Module to Improve Students' Learning Outcomes in State Vocational High School 1 Karanganyar
}

\author{
Abdur Risman; Sigit Santoso \\ Postgraduate School, Universitas Sebelas Maret, Indonesia
}

http://dx.doi.org/10.18415/ijmmu.v6i2.946

\begin{abstract}
This research aimed to determine the effectiveness of guided inquiry-based accounting learning modules to improve the students' learning outcomes in State Vocational High School (SVHS) 1 Karanganyar. This research is a research and development ( $R$ \& D). This media development model used the design from Borg \& Gall. The test was conducted in two classes, namely class XI AK 1 (experimental class) and XI AK 2 (control class) at SVHS 1 Karanganyar. The analysis prerequisite tests included normality test, homogeneity test, and t-test. The analysis technique used is qualitative and quantitative descriptive. The results of the research on the effectiveness of guided inquiry-based accounting learning modules show that $\mathrm{t}>\mathrm{t}_{\text {table }}=(0.248>1.99)$, then $\mathrm{H}_{0}$ is rejected. It means that the two groups have different learning outcome scores. The posttest results between the experimental class (using the developed learning module) and the control class (not using the developed learning module) showed that the mean score of the experimental class was 80.45, which was higher than that of the control class of 73.77. It can be summed up that the development of guided inquiry-based accounting learning modules is effective in improving the students' learning outcomes in SVHS 1 Karanganyar.
\end{abstract}

Keywords: Development; Learning Module; Guided Inquiry

\section{Introduction}

Education is one of the means to create quality human resources (HR). This quality human resources (HR) will build a country to improve the quality of the nation. One of the government's efforts to improve the quality of education is by reforming the curriculum. In 2013, the Indonesian Government through the Ministry of Education and Culture carried out curriculum reform which was an improvement from the previous one. The 2013 curriculum focus on not only cognitive development, but also attitude development in both spiritual and social attitudes, as well as the development of students' skills. This is reflected in the content standards used in the 2013 curriculum as stated in Permendikbud No. 64 of 2013 concerning Content Standards (Minister of Education and Culture Republic of Indonesia, 2013a).

The implementation of the learning process in the 2013 curriculum places teachers as facilitators of learning. They must be able to transfer learning material interestingly to make it easier for students to absorb and apply it in their daily lives. In the 2013 curriculum, each subject has core competencies that 
must be implemented in learning and possessed by students. The core competencies achieved and possessed by students must be balanced between hard skills and soft skills.

Based on the results of preliminary observations at State Vocational High School (SVHS) 1 Karanganyar, the researcher found several problems in the application of the introduction to financial accounting subject in the 2013 Curriculum; they are: (1) lack of teaching materials that could be used by teachers in the learning of introduction to financial accounting in the 2013 curriculum; (2) students were less active in the learning process; (3) learning programs had not been able to make students independent; and (4) the learning process was still teacher-centred.

One solution in improving students' absorptive capacity and cognitive skills is by using the appropriate learning methods and models. Learning methods and models in the introduction to financial accounting subject are expected to improve students' cognitive, affective and psychomotor domains. Improving brain power in the education process is a set of skills that can be developed through the learning process (Rosalin, 2008).

Based on this description, it is necessary to develop a teaching material in accordance with the learning of the introduction to financial accounting in vocational high schools. The most appropriate teaching material to be developed is a module. A module is a complete unit that stands alone and consists of a series of learning activities arranged to help students achieve several objectives specifically and clearly formulated (Nasution, 2010, p.205).

Learning activities carried out by the teacher will be interesting if he integrates teaching materials with learning models as an effort to increase the students' activeness in exploring knowledge and applying students' creative ideas to improve their learning outcomes. The choice of learning model must be adjusted to the material being taught because the learning model will make learning activities more interesting and make students more enthusiastic about learning. Therefore, the idea emerged in compiling a learning module by packaging the learning material combined with interesting learning models.

One of the models in question is a guided inquiry-based learning model that is a learning model that uses relevant information collection methods and logical analysis through investigation and investigation of surrounding phenomena with instructions in the form of guiding questions. Thus, students solve problems based on the facts they have found (Joyce and Weil, 2011: 103). The guided inquiry-based learning model is an inductive learning method as it presents the surrounding phenomena into the classroom, so students are encouraged to construct their knowledge through the interaction between their experiences and the surrounding phenomena (Rusche and Jason, 2011: 338-353). Learning using a guided inquiry model gives students the opportunity to build their knowledge and helps them develop an understanding of a concept (Pandey, et al., 2011; Stricklyn, 2011; Lee, et al., 2010; Minner, et al., 2010; and Wilson, et al., 2010).

With the development of the financial accounting learning module compiled based on content standards, it is expected to add references to accounting learning activities. In addition, the module developed is expected to be one example for accounting teachers in developing teaching materials in the form of modules. The modules developed by the researcher was implemented in introduction to accounting learning subject at SVHS 1 Karanganyar to determine the feasibility and effectiveness of the module developed. 


\section{Method}

This research is a research and development. This development model in this research follows the design of Borg \& Gall (1983: 775) which consists of 10 steps. They are: (1) collecting information and conducting preliminary research; (2) planning; (3) developing the preliminary from of the product; (4) preliminary trial field testing; (5) main product revision; (6) main field testing; (7) product revisions from operational product revision; ( 8) operational field testing, (9) final product revision, and (10) dissemination and implementation. Before the trial was conducted, the module product of guided inquiry-based accounting learning was validated first by the media expert, material expert, practitioner and linguist. Then, the product was revised.

The test subjects in this research were the students of class XI Accounting at SVHS 1 Karanganyar. The preliminary trial subjects were 10 students and field-trial subjects were 25 students from class XI Accounting 2. The subjects for the operational field trials in the experimental class were 35 students and the control class 36 students of class XI 3 Accounting 3.

\section{Discussion}

The application of the guided inquiry-based accounting learning module began with the needs analysis phase. The development model used is product development with the steps of Borg and Gall, which consist of needs analysis, design, development and implementation phases. In the first phase, the analysis consisted of two stages, namely literature study and needs analysis. In the first stage, the researcher conducted an analysis of the problems to develop instructional media of the introduction to financial accounting by conducting observations and interviews with accounting teachers. After finding the problems found in the field, the next step was formulating the objectives of developing learning media in the form of the accounting learning module. Based on the results of the field study and the analysis phase, the problem about the teacher's difficulty in delivering the material of the introduction to financial accounting was identified because of the limitations of teaching materials.

The second phase is determining the scope of the material to be set forth in the accounting learning module that has been adapted to the curriculum that applies to SVHS 1 Karanganyar by designing the initial module. The making of module design and draft of the accounting learning module was adjusted to the steps in the guided inquiry-based learning model, so that the typical features of the module were developed. The format of the inner part of the guided inquiry-based accounting learning module consists of the cover page section, the module introduction section, the core module section, and the end of the learning module.

During the trials, the researcher collected the shortcomings which still needed improvement. After the initial product had been made, the next step was testing. Product evaluation was validated in two stages, internal and external validations. Internal validation is in the form of validation carried out by the media expert, linguist, practitioner and material expert. The external validation is an assessment carried out by users, namely student participants of class XI Accounting Expertise Program in SVHS 1 Karanganyar.

The third is the development and implementation phase, which began with product validation by the material expert, linguist, practitioner and media expert, followed by a validation test of product feasibility. According to Daryanto (2010, p. 22), validation is a process to test the suitability of media with competencies that are the target of learning. The implementation phase is a field test stage in two class groups (experiment and control). The experimental group is a group of students who use the inquiry-based accounting learning module while the control group is the group of students who use 
textbook teaching materials. The product effectiveness test was done to get a feasible and quality product in terms of material content and the module itself. After the product was declared feasible, this learning media could be used in the accounting subject. The product feasibility analysis was obtained from the results of filling out questionnaires/evaluation sheets from the material expert, media expert, linguist, practitioner and product trial questionnaires that have been filled out by the students. For the effectiveness of the product, it was obtained from the achievement test.

Based on the feasibility criteria of the guided inquiry-based accounting learning module, the assessment of the learning material expert resulted in an average aspect of 81.53 (very good), the media expert 84.48 (very good), the practitioner 94.03 (very good), and the linguist 100 (very good). Based on the Independent Samples Test of the pretest of the experimental class and the control class, it is known that the significance value of the t-test is 0.248 . The significance value is greater than 0.05 , which means that $\mathrm{H}_{0}$ is not rejected and the $\mathrm{t}$ value is $0.248<\mathrm{t}_{\text {table }}$ equal to 1.99 . This shows there is no difference in the significance of the average student learning outcomes between the experimental class and control class at the pretest. Then, both the experimental class and the control class were given a treatment. The experimental class was given treatment using the guided inquiry-based accounting learning module while the control class was not given a learning module but learned to use available the textbook at school. This means that the experimental class was given treatment in the form of a learning module that had been developed and the control class was not treated using the module.

The posttest mean score of the experimental class is 80.45 while that of the control class is 73.77. Based on the results of the assessment, it is known that the score obtained by the experimental class is higher than that obtained by the control class. The mean score of the experimental class before using the guided inquiry-based accounting learning module was 67.56. After treatment using the guided inquiry-based accounting learning module, the posttest mean score increased to 80.45 . The results of the increase in the mean score of learning outcomes in the introduction to financial accounting subject before (pretest) and after (posttest) using guided inquiry-based accounting learning modules indicate that the accounting learning module effectively improves students' learning outcomes. This is supported by the research of Chung-Suk et al (2013: 102) stating that learning with guided inquiry-based modules effectively promotes better scientific skills of students.

Based on this description, we can know that the use of instructional media is an integral factor to improve students' learning outcomes in the learning process because learning media is one of the tools that are very supportive in developing the knowledge that students have, especially in the learning process at school. . Therefore, the school should pay attention to and provide interesting learning media for students so that the learning process in the classroom can run effectively.

\section{Result and Conclusion}

Guided inquiry-based accounting learning modules effectively improve students' learning outcomes. The effectiveness of the accounting learning module is based on the results of the pretest (before using guided inquiry-based accounting learning modules) with the mean score of 67.56 and the posttest (after using guided inquiry-based accounting learning modules) mean score of 80.45 during the field trial. The increase in the mean scores of the pretest and posttest learning outcomes using guided inquiry-based accounting learning modules on learning shows that guided inquiry-based accounting learning modules are effective in improving students' learning outcomes.

The use of guided inquiry-based accounting learning modules effectively improves students' learning outcomes supported by statistical calculations with the significance value of $0.002<0.005$. The effectiveness test between the experimental class and the control class showed a significant difference. 
The mean score of the experimental class was 80.45 and control class 73.45. Based on the mean score of posttest learning outcomes (after treatment), it can be concluded that there is an increase in the mean score of learning outcomes after using the guided inquiry-based accounting learning module.

\section{References}

Borg, W.R., \& Gall, M.D. (1983). Educational research: an introduction. New York: Longman.

Cho, Chung Suk., Cotrell, David S., Mazze, Candace E., Dika, Sandra, \& Woo, S. (2013). Enhancing Education of Construction Materials Course Using Guided Inquiry Modules Instruction. Journal of Professional Issues in Engineering Education \& Practice. Vol. 139. Issue 1. Pp. 27-32

Daryanto. (2010). Media pembelajaran (Learning media). Yogyakarta: Gava Media.

Joyce, B \& Weil, M. (2011). Model of teaching (eight edition). Yogyakarta: Pustaka Pelajar.

Minner, D. et al. 2010. Inquiry based science instructions what is it and does it matter? Result from a research synthesis years 1984 to 2002. Journal Research in Science Teaching 143(1): 527-553.

Nasution. (2010). Berbagai Pendekatan dalam Proses Belajar dan Mengajar (Various Approaches in the Teaching and Learning Process). Jakarta: Bumi Aksara.

Pandeley I. et al. (2011). Effectiveness of inquiry training model over conventional teaching method on academic achievement of science student in India. Journal of Innovative Research in Education 3(2): $7-20$.

Rosalin, E. (2008). Guru dalam meningkatkan daya pikir siswa (Teachers in improving students' brain power). Jurnal Manajemen Pendidikan UPI, Year IV. (No.01).

Rusche, S.N., \& Jason, K. (2011). You have to absorb yourself in it: using inquiry and reflection to promote student learning and self-knowledge. American Sociological Association 39(4): 338-354.

Stricklyn, J. (2011). What effect will using inquiry methods of teaching science have on sixth grade students? Montana State: University Library.

Wilson, C.D. et al. (2010). The relative effects and equity of inquiry based and common place science teaching on students, knowledge, reasoning, and argumentation. Journal of Research in Science Teaching 47(5): 276-301.

Zion, M. \& Sadeh, I. (2011). Which type of inquiry project do high school biology students prefer? Open or Guided. Research Science Educatio 42, 831.

\section{Copyrights}

Copyright for this article is retained by the author(s), with first publication rights granted to the journal. This is an open-access article distributed under the terms and conditions of the Creative Commons Attribution license (http://creativecommons.org/licenses/by/4.0/). 